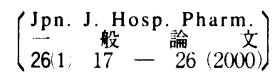

\title{
糖尿病患者への服薬カウンセリングと医療薬学実践教育について†
}

\author{
荒木博陽 $\dagger^{2}$, 川崎博已 $\dagger^{3}$, 出石通博 $\dagger^{2}$, 二神幸次郎 $\dagger^{2}$, 四方賢一 $\dagger^{4}$, \\ 和田 淳 $\dagger^{4}$, 杉本 光 $\dagger^{4}$, 久代昌彦 $\dagger^{4}$, 槙野博史 $\dagger^{4}$, 五味田裕 $\dagger^{2}$ \\ 岡山大学医学部附属病院薬剤部 $\dagger^{2}$ \\ 岡山大学薬学部医療薬学専攻臨床薬学 $\dagger^{3}$ \\ 岡山大学医学部附属病院第 3 内科 $\dagger^{4}$
}

\section{The Individual Medication Counseling to the Outpatient with Diabetes Mellitus by the Stuff of Faculty of Pharmaceutical Sciences and Clinical Training for the Students $\dagger^{1}$}

\author{
HIROAKI ARAKI $\dagger^{2}$, HIROMU KAWASAKI $\dagger^{3}$, MICHIHIRO IZUSHI $\dagger^{2}$, KOUJIRO FUTAGAMI $\dagger^{2}$, \\ KENICHI SHIKATA $\dagger^{4}$, JUN WADA $\dagger^{4}$, HIKARU SUGIMOTO $\dagger^{4}$, MASAHIKO KUSHIRO $\dagger^{4}$, \\ HIROFUMI MAKINO $\dagger^{4}$ and YUTAKA GOMITA $\dagger^{2}$ \\ Department of Hospital Pharmacy, Okayama University Medical School ${ }^{2}$ \\ Department of Clinical Pharmaceutical Science, Faculty of Pharmaceutical Sciences, Okayama University $\dagger^{3}$ \\ Department of Medicine III, Okayama University Medical School $\dagger^{4}$
}

\author{
$\left(\begin{array}{l}\text { Received April 15, } 1999 \\ \text { Accepted September 20, 1999 }\end{array}\right)$
}

Individual medication counseling for outpatient with diabetes mellitus was carried out by an instructor who was a faculty staff member of the department of pharmaceutical sciences (DPS) as a part of pharmaceutical clinical training of pharmacy students. The team instructor from the faculty of DPS and a hospital pharmacist investigated the chart of the patient with diabetes mellitus based on a request from a doctor, and according to the counseling policy, it counseled the patient after first discussing the details with the doctor. Pharmaceutical students observed this process as part of their training. Although the drug specifies had already been explained to the patient by the doctor, for ther details regarding the pharmacological contents of the dosing drug, the drug efficacy at the application, dose, side effects, especially hypoglycemia, etc. were explained to the patient. As some patients have other diseases besides diabetes mellitus, the effects of drugs for other diseases were also explained. The report was made after finishing all counseling, and was submitted to the doctor. The participation of faculty members from the DPS in clinical training is an effective method for educating students. In addition, it is also important to increase the numbers of opportunities for hospital pharmacists to share clinical experience with the faculty member of the DPS. It is therefore necessary to increase the mutual cooperation between the faculty staff members of the DPS and hospital pharmacists to improve the overall education of pharmacy students.

Key words - medication counseling, instructor from the department of pharmaceutical sciences, clinical pharmacy education, diabetes mellitus patient 


\section{緒}

薬剤師は医療法の改正により法的にも医師や看 護婦等の他の医療スタッフとともに医療の担い手 の一員として位置づけられ，患者に対する薬物療 法に大きな関与をすることになった。 また，病棟 に打ける服薬指導業務の必要性の増加に伴い，医 療チームとしての業務の内容が多岐に渡ってきて おり，その職能を発揮する上で, 薬学部における 臨床実習の充実が求められ, 病院薬郕部での実践 教育が不可欠なものとなってきている ${ }^{1,2)}$.それ に伴い, 実践教育については薬学部, 薬科大学に おいてすでにカリキュラムに組み込まれ，実習期 間の延長あるいは全員必修化への取り組みがなさ れつつあるのが現状である。しかし，この実践教 育は病院の薬剤師に依存して行われることがほと んどであり, 病院での薬剤業務を行いながら指導 を行う薬剤師側にとっては大きな負担となってい ることは否めない，とくに最近の学生が希望する 患者への服薬指導業務の実践教育は患者への配 慮, 担当医師あるいは看護婦, 彼らの上司（教授 あるいは担当部長, 婦長等) の事前の了解, 実習 時間等の関係で難しい問題が多い，薬系大学にお ける事前の導入講義やプレトレーニングあるいは 模擬薬局など(-5)で学生は一応の準備のもとに各 病院での実務実習に臨むわけであるが, 患者を前 にした実践教育実習は現場における病院薬剤師の きめ細かい配慮とサポートがなければなかなか実 習の成果を上げられないのが現状であろう。

ところで, 日本においては病院での薬学生への 直接の指導に薬学部教官が参画することは極めて 少ないのではないかと思われる. 一方アメリカに おいては, アラバマ州の Sunford 大学のように7 〜 8 人の薬学部の教官が週に $1 \sim 2$ 回契約を結ん

$\dagger^{1}$ 本報の要旨は第 8 回日本病院薬学会年会(横浜, 1998年, 9月)で発表.

$\dagger^{2.4}$ 岡山市鹿田町2-5-1；2-5-1, Shikata-cho, Okayama-shi, 700-8558 Japan

$\dagger^{3}$ 岡山市津島中1-1-1;1-1-1, Tsushima-naka, Okayama-shi, 700-0082 Japan
だ研修病院の現場で臨床サービスを行いながら学 生を指導している( ${ }^{6}$. 平成 9 年 8 月 1 日から 8 日 まで開催された東アジア医療薬学カンファレンス (East Asia Conference on Developing Clinical Pharmacy Practice and Education)においては，実際に Sunford 大学の教官が在宅医療提供の現場や薬局 あるいは臨床現場で患者に対して服薬指導してい る様子を見学させている。半谷(6)はその様子を報 告しているが, 薬学生たちは指導教官に，その日 の検査值から患者の状態を考慮した薬物投与量を 報告し，教官はその報告を受けた後，自ら病棟に 学生を連れて行き, 投与量の変更の指示を患者の カルテに記入している. 学生への指導は学生が示 した報告が正しいのか，誤っているとすればどの ように䛊っているのかについて，患者のデータ， カルテを見ながら指導している. 当然, 教官の給 与は薬学部と病院から支払われることとなる（R. D. Lander 私信).このように, 臨床サービスを行 う薬学部の教官が存在することが日本の実践教育 と大きく異なる点である.

そこで, 米国ですでに実施されている薬学部教 官が参画する，とくに患者と直に接する機会のあ る実践教育が日本でも実現できないものかと考 え, 外来糖尿病患者への個人的な服楽カウンセリ ングを行うこととした。その中でいかに薬学部教 官が医師打よび病院薬剛師と連動して患者への服 薬カウンセリングを行い, それを学生への実践教 育とすることができるかについて検討したので報 告する.

なお，服薬カウンセリングは担当教官が一方的 に服薬指導するのではなく，患者の訴えを聞き， 薬に関するさまざまな疑問あるいは注意事項を質 疑応答形式でやりとりする方式で実施した。

\section{方法}

\section{1. 薬学部教官への服薬カウンセリング委啒}

今回は初めての試みであることを考慮して, 薬 学部服薬指導教官の参画については, 薬剤部から 実務経験のある教官 1 名を指名し, 病院（長）か 
ら薬学部（長）に対して，その教官に服薬カウン セリングを委嘱し, 薬学部（長）がその教官が服 薬カウンセリング教育に従事することを教授会に 諮り承諾する形式を取った。

\section{2. 対象患者}

対象は初期の外来糖尿病患者とした。

\section{3. 服薬カウンセリング担当者}

薬学部教官と薬郕部の担当薬剈師 (副薬剤部 長, 医薬品情報室担当主任等）でチームを組み， 服薬カウンセリングを行った。

\section{4. 服薬カウンセリングの方法}

一連のカウンセリングの実施方法を図 1 に示 す. 担当医師が患者受診時に服薬カウンセリング が必要と判断した患者に対して, 服薬カウンセリ ング依頼書を発行する．服薬カウンセリング担当 チームは服薬カウンセリング依頼書に沿って, カ ルテを閲覧して病態や臨床検査值等患者情報の収 集を行う.その後, 担当医師とのミーティングを 通して, 服薬カウンセリング内容を確認する. 服 薬指導カウンセリングは, 患者の次回来院時に行 い，服薬カウンセリング記録をもとに報告書を作 成し, 担当医師に提出し, 医師への情報のフィー ドバックを行った。

\section{5. 学生指導}

服薬カウンセリングを行っている現場を患者に 了解を得た上で, 現在のところ医療薬学専攻大学 院生を服薬カウンセリングの場所に同席させた。

\section{結果}

1. 服薬カウンセリング依頼書の発行および チェックリストの作成

図 2 に服薬カウンセリング依頼書の代表例を示 した。医師が必要事項を記載し，薬剤部に提出し た。薬剤部担当者は服薬カウンセリング依頼書か ら糖尿病のタイプ，病態，治療状況，合併症，投 与薬剤についての情報を入手し，それら情報をも とに薬学部担当教官とともに，次の来院日すなわ ち服薬カウンセリング日までに服薬カウンセリン グ事前チェックリスト（図３）に沿って，カルテ を参考に必要事項のチェックを行った。すなわ ち，年齢，体重，職業，家族歴等の患者情報，受 診記録, 主訴, 診断名, 病歴, 諸検査值, 臟器障 害，合併症，治療方針，他診療科抢よび他医療機 関受診状況, 既往歴, 投薬歴, 副作用歴（アレル ギー), 理解度等である。

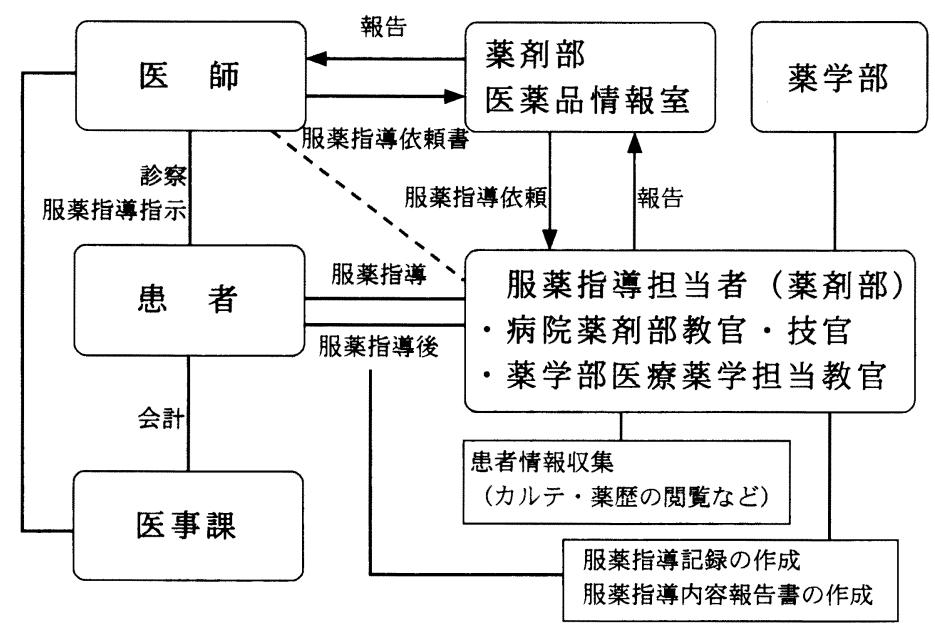

図 1.カウンセリングの実施方法 


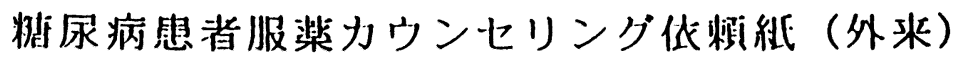

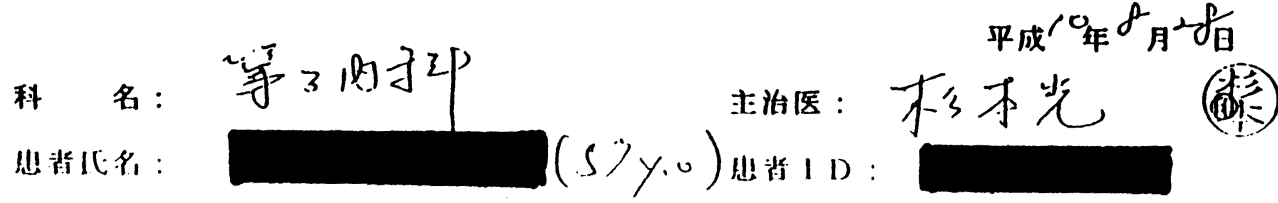

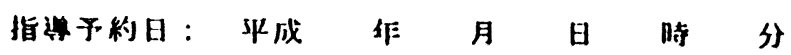

投与菓用:

・インスリン

・程口监脂降下刹

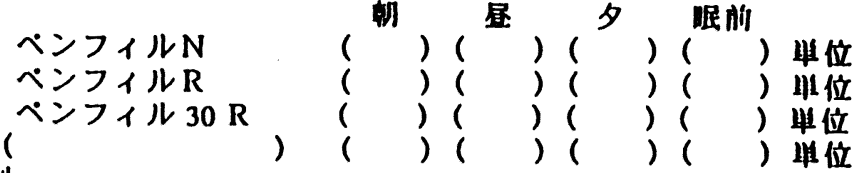

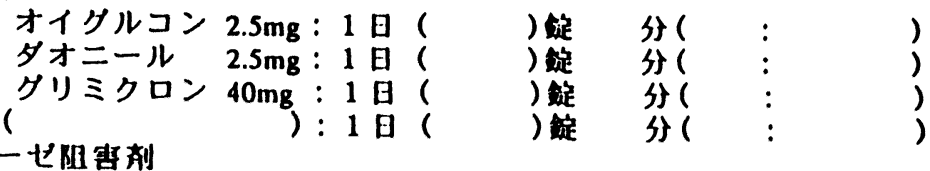

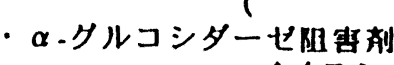

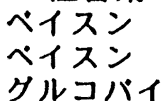

$$
\begin{aligned}
& \text { ・インスリン低抗性改暜刹 }
\end{aligned}
$$

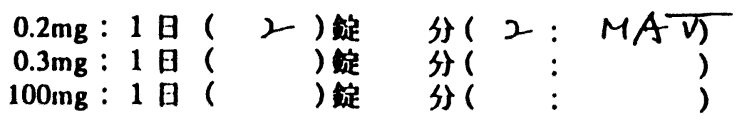

$$
\begin{aligned}
& \text { ノスカール } \\
& \text { : 1日() 促 }
\end{aligned}
$$

泊类犹沉

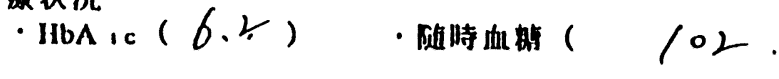

合作宿

- 利経症

$$
\text { 投与浆绪 }
$$
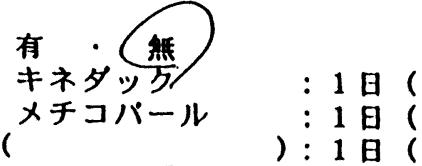

$$
\text { ) 稓 }
$$

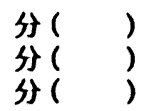

- 哏合侀症 有 .

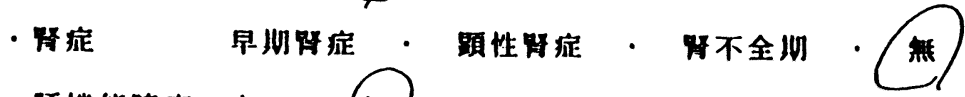

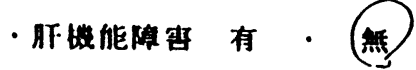

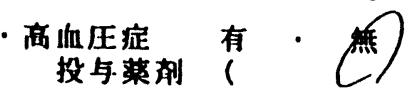

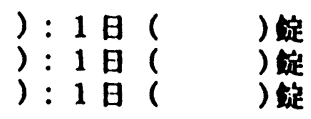

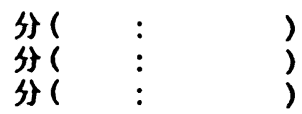

・高脂血症

\section{投与䔉郕}

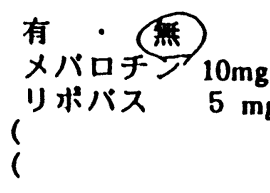

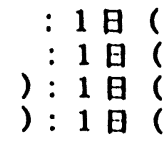

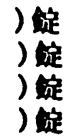

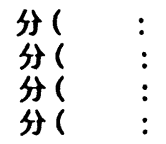

・その他の合作症・投与韯刹

$$
\text { 持い子し。 }
$$


糖尿病患者服薬カウンセリング前チェックリスト

平成 10 年 10 月 21 日

患者氏名：

科名: 第三内科
患者 I D : 00-000-00

主治医 : 杉本 光 医師

患者情報：生年月日・年龄：昭和 16 年 1 月 29 日

性別 : 女性

身長・体重 : $154.0 \mathrm{~cm} 、 55.0 \mathrm{Kg}$ B M I : 23.2

僮業：主婦

家族笨成：

家族歴：不明

性格：

嗜好：眒酒；なし・契煙；なし

Appetite - Sleep : Good

理解度 : 要碓認

受診記録：初祅年月日：平成元年 10 月 18 日

主即：不明（旧カルテ分冊のため確認できず）

診断：インスリン非依存型糖尿病（疑い）

平成 8 年 4 月より主治医: 岡田先生より杉本先生に

榶尿病については食事療法により血糖コントロール良好

検 查 值 :

平成 8 年 7 月 4 日

9 月 5 日

平成 9 年 3 月 15 日

5 月 9 日

11 月 14 日

平成 10 年 4 月 24 日

8 月 2 日

$\mathrm{Hb} A \mathrm{c}$

6. 1

5. 9

5. 8

5. 9

6. 2

6. 0

6. 2

\begin{tabular}{|c|c|c|} 
空腹時血梼 \\
9 & 0 \\
& 8 & 6 \\
9 & 8 \\
1 & 0 & 5 \\
1 & 0 & 7 \\
1 & 0 & 3 \\
1 & 0 & 2
\end{tabular} \mid

体重 $(\mathrm{Kg})$

52 . 5

53.5

55.0

5 5. 0

\begin{tabular}{|c|c|c|c|c|}
\hline OG & 0 分 & 15 分 & 30 分 & 60 分 \\
\hline 1 & 99 & 166 & 139 & 122 \\
\hline 戈 & 0 & 176 & 160 & - \\
\hline
\end{tabular}

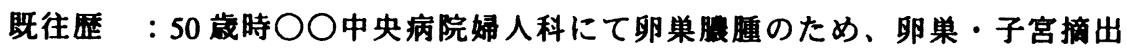

平成元年 10 月、岡山大学医学部附属病院耳咽喉科に突発性難俧にて入院

器器障 : なし

※第三内科には入院検查時の異常により紹介

合併症：心疾患・肝疾患・略疾患・高血圧症等；なし

治寮方針：食事療法：第三内科初診時に栄養士より指導有り

運動療法: 同・医師より指学有り

薬物痖法: 平成 10 年 8 月 28 日：境界型 NIDDM の疑い

睟被 $\beta$ 細胞の負担軽娍のためべイスンを処方

困 3。服薬カウンセリング事前チェックリスト（その1） 
他診療科受診状況：産科婦人科

眼科に年 1 回糖尿病性病変検査のため受診

他医療機関受診状況: 平成 10 年 6 月 $\bigcirc$ 中央病院整形外科

腰甶のため受診、投莧歴不明のため確認のこと

既 往 歴

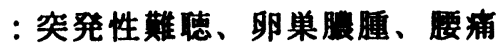

投薬歴: (1)医㞠用薬

第三内科

10.8.28 ベイスン $(0.2 \mathrm{mg}) \quad 2 \mathrm{~T} 2 \times(30)$ M, A V.d.E. ※院外処方にて、1 日 1 錠より開始、現在 1 日 2 錠に 産科婦人科

$\begin{array}{llllll}9.10 \sim & \text { プレマリン } & (0.625 \mathrm{mg}) & 2 \mathrm{~T} & 2 \times() & \mathrm{M}, \mathrm{A} \\ & \text { プロベラ } & (2.5 \mathrm{mg}) & 1 \mathrm{~T} & 1 \times() & \text { V.d.S }\end{array}$

※ホルモン㭪充痖法のため

(2)一般薬・民間薬・健康食品等

患者に要確認

副作用歴：なし

アレルギー：なし

備考：

服薬指学内容 :

I . $\alpha$-グルコシターーセ阻害郕 : ペイスン $0.2 \mathrm{mg}$

(1)嵲効・薬理：作用機序

(2)効能・効果

(3)用法・用基：1日 2 回 1 回 1 錠 朝・夕の食直前投与の強調

(4)相互作用

(5)副作用

低血糖 : 症状・対処方法 (ブドウ糖服用指示等)

消化器症状 :

肝機能障害 :

(6)保管方法

(7)一般的注意 :

(8)その他の注意 : コンプライアンス、飲み忘れた場合、大量投与時 等

II . ホルモン㭪充療法について 


\section{2. 担当医師との事前打ち合わせ}

薬学部教官と薬片部担当者は患者についての服 薬カウンセリング方針をチェックリストに基づ き, 決定した. カウンセリングを行う上での必要 事項や留意点あるいは疑問点については担当医師 に確認した。確認方法としては面談あるいは電話 で意志の疎通を図り, 患者へのカウンセリングで 医師の説明等との間に食い違いがないように留意 した.

\section{3. カウンセリングの実際}

患者へのカウンセリングは次回の来院時に行っ た。 その日は薬学部教官は午前中より病院に待機 し, 患者が診察終了後に薬剤部に来られた折りに カウンセリングを実施した. 投与薬剤の薬学的内 容については，すでに説明済みのことであって も, 新たに一般的注意, 薬効・薬理, 効能・効果, 用法・用量, 相互作用, 副作用とくに低血糖時の 対処法, 薬物の保管方法, 飲み忘れの注意等につ いて説明した，医師との事前打ち合わせで，説明 内容に医師の希望が含まれる場合は医師の希望す る範囲でのカウンセリングとした。 また，糖尿病 に関する薬剈だけでなく, 併用されている薬物に ついても可能なかぎりの説明を加え，患者の疑問 に答えた。このようなカウンセリングの場に医療 薬学専攻学生を同席させ, 服薬カウンセリングの 様子を観察記録させた。

\section{4. 服薬カウンセリング報告書の作成}

服薬カウンセリング終了後にその内容をもとに 報告書を作成し，それを医師に提出することによ り，服薬カウンセリングに関する情報のフィード バックを行った。

\section{5. 服薬カウンセリングの実施例}

症例 1

患者：49歳 女性

身長・体重： $157 \mathrm{~cm}, 42 \mathrm{~kg}$

嗜好：飲酒；ビール $350 \mathrm{~mL} /$ 日 喫煙；なし 受診記録: 平成 10 年 5 月 8 日初診

主訴：2３年前から目がかすむこととのど が渴くことを自覚. 平成10年初め頃, ウエ
スト周りがやせていることに気づき， 4 月 上旬 $47.5 \mathrm{~kg}$ あった体重が 1 力月で $5 \mathrm{~kg}$ 減 少. 4 月下旬に薬局で購入した尿糖検査紙 で検査したところ強陽性. 検査目的で外来 受診.しびれや手足の感覚異常はなし.

診断：NIDDM（インスリン非依存性糖尿病） 合併症 : 高脂血症

検查值：平成10年 5 月 8 日 5 月15日 $\mathrm{HbA} 1 \mathrm{c} \quad 11.6$

食後随時血糖 345268

検查值： 5 月29日

HbA $1 \mathrm{c} \quad 10.9$

食後随時血糖 195

臟器障害：なし

治療方針：栄養指導 平成10年 7 月 31 日実施 糖尿病食 : $1,200 \mathrm{kcal}$

薬物療法：インスリン; ペンフィル R, ペリ シット

既往歴：薬物アレルギー

投薬歴：医療用薬； 5 月15日

$$
\text { ペンフィル R: } 4-4-4
$$

服薬カウンセリング：

服薬カウンセリングに先だって医師にカウ ンセリング実施上の留意点を確認したとこ ろ,本患者は仕事の都合で入院ができない とのこと, 初発であること, 糖尿病につい ては本や家族からの情報でかなり詳しく 知っていること, すでにインスリンを自己 注射されていることなどの情報を入手し た. 医師からは主として薬物の説明, 低血 糖時の留意点を説明してほしい旨連絡を受 けていたので,低血糖時の対応については プリントを渡し, 説明した。また, 高脂血 症の程度について医師に確認したが，トリ グリセリドが高値ということでニコチン酸 系薬剤ニセリトロールを処方されていた. この薬についても使用上の留意点等説明し た。患者とのカウンセリングでは患者から 糖尿病と気づく経緯, 仕事との関係, 現在 
のインスリン自己注射の大変さ, 高脂血症 のこと等が語られた。薬凨師側からは患者 の質問に答えるとともにインスリンの注射 凰について, 自己注射の場所や注射方法, 低血糖時の対応, 高脂血症と糖尿病の関連 性等について説明した。

症例 2

患者：57歳 女性

身長・体重：154cm，55kg

嗜好：飲酒；なし 喫煙；なし

受診記録：平成元年10月18日初診

主訴：食事療法・運動療法にて血糖コント ロールされていたが, 空腹時血糖值が 上昇した。

診断：NIDDM（インスリン非依存性糖尿病） 疑い

合併症：なし

検查值：平成 8 年 平成 9 年 平成 10 年 9 月 5 日 11 月 14 日 8 月28日

$\begin{array}{lcrr}\mathrm{HbA} 1 \mathrm{c} & 5.9 & 6.2 & 6.2 \\ \text { 空腹時血糖 } & 86 & 107 & 102 \\ \text { 体重 }(\mathrm{kg}) & 52.5 & 55.0 & 55.0\end{array}$

臟器障害：なし

治療方針：食事療法; 初診時, 栄養士より指 導あり

運動療法 ; 初診時, 医師より指導あり

薬物療法; 平成10年 8 月28日の来院時よりボ グリボースを処方

既往歴：50歳時に卵巣腫瘍のために卵巢・子 宮摘出, 平成元年突発性難聴

投薬歴：平成10年 8 月28日よりボグリボース (ベイスン) $0.2 \mathrm{mg}$ を 1 日 1 錠よ り開始，現在 1 日 2 錠。産科婦人 科からホルモン補充療法としてエ ストロゲン(プレマリン) $0.625 \mathrm{mg}$ 1 日 2 錠, メドロキシプロゲステ ロン (プロベラ) $2.5 \mathrm{mg} 1$ 日 1 錠.

服薬カウンセリング :

担当医師の話では，本患者は以前より血糖
值が高めであり，食事療法および運動療法 で血糖コントロールがうまくできていた が，最近空腹時血糖值が 100 を超えるよう になったため，䐙臓 $\beta$ 細胞の負担軽減のた めにボグリボースを処方しているとの説明 があった。ボグリボースの用法・用量、低 血糖症状や留意点について説明して欲しい との依頼があった。そこで，当院で作成し た「糖尿病のくすりのしおり」をもとに 「この薬の使い方」，「この薬を飲んだあと 気をつけていただくこと」、「生活上の注 意」などを説明し，低血糖症状が現れた時 の対処法について詳しく説明した。また， 副作用として報告されている肝機能障害に ついても説明した。ささらに，ホルモン療法 についても薬の概略について説明し，患者 からの質問に答えた。

\section{6. 学生指道}

医療薬学専攻大学院生を患者の了解の上で同席 させ，薬学部教官による服薬指導カウンセリング の様子を見学させた，患者は薬物についての教官 からの説明を聞くだけではなく，自分の病状や医 師からの指示, 糖疗病を治療する上でのつらいこ とや気にしていること，あるいは検査值や別の疾 患の薬物についても質問してくることが多い，患 者の訴えを聞きながら，的確に疑問に答え，相談 を聞き，アドバイスすることが重要である。その 様子を学生に見学させ，終了後に，当日患者から 得られた情報も加えて，指導に対する感想，気づ いたこと，カウンセリングとして加えるべき項 目，さらに調査しておくべき点など，その日の患 者とのカウンセリングについて討議している，学 生からは，薬学部の講義の時と違う雲囲気があ り, 薬学の教官も医療の一端に参加しているとい う実感を感じられるとのコメントが多く聞かれ た。 


\section{考察}

薬学部教官が臨床現場である病院において, 実 践教育として外来糖尿病患者の服薬カウンセリン グに参画している現状について報告した，糖尿病 患者で服薬カウンセリングが必要と医師が判断し た患者は初期糖尿病の者から，血糖コントロール がうまくできない者まで幅広く，また，他の疾患 を有している患者が多かった。さらに，外来で糖 尿病治療を受けている患者には入院して治療を受 けた方がよいと判断される患者も多いが，仕事の 関係，家庭環境，あるいは時間的制約等でやむを 得ず外来治療を余儀なくされる患者がほとんどで あった. 本カウンセリングを開始した当初は, 医 師も配慮して，若くて理解力のある患者を指定し ていたが，服薬カウンセリング依頼書が発行さ れ, カウンセリング予定の次回の来院時に, 薬剤 部に寄ることなくそのまま帰られる患者が続き， 対応を迫られた，後日理由を尋ねると「時間がな かった」、「忘れていた」等のことであったので， その対策として服薬カウンセリングの当日に「糖 尿病を治療するお薬の話を聞かれる患者さんへ」 という薬剤部への地図をつけた案内パンフレット をカルテにはさんでおき, 診察当日医師より患者 に渡してもらうようにしたところ，そのまま帰る 患者はなくなった。さらに，医師が忙しい患者を 避け，時間的に余裕のある患者を服薬指導カウン セリング対象患者として指名するという配慮をし たこともまた大きな要因である.

患者へのカウンセリングにおいて重要な点は, 事前に医師とのコミュニケーションを十分に図る ことである。医師からの依頼書やカルテによる情 報だけでは不十分なことも多く，必ず服薬カウン セリング実施前には医師とコンタクトを取り，患 者とのカウンセリングにおける注意点を確認して おく必要がある．上記代表例以外に，他科の診察 を受け，処方された薬物が糖尿病患者に対して慎 重投与の注意のある薬郕であった例もあった（乾 せん治療薬：エトレチナートが皮膚科から処
方).このような場合は, 特に事前に使用上の注 意やどのような説明を必要とするかなどの打ち合 わせが必要である.また, 服薬カウンセリング後 に報告書を作成し，医師に情報をフィードバック し，その後の診療に役立ててもらうことも重要な ことであろう。学生は教官が服薬カウンセリング を行う実際を見て, 記録として残すことでカウン セリング終了後にわからなかったこと, 自分なり の考え方，患者との接し方等について担当教官と 質疑応答を行うことが可能となった。 ただ単に講 義の中で知識のみを吸収するのではなくて臨床現 場で患者の声を聞きながらの実習は，これから自 分が病院薬浏師として働く上で, 勉強しなければ ならない範囲の広さを認識するものではないかと 思われた。

患者とのカウンセリングは糖尿病という疾患に 限らず，合併症あるいは他の疾患のことまで話が 及ぶことが多い，話題は薬のことに限らず，病態 や原因あるいは精神的，身体的な苦痛などきわめ て多岐に渡る。薬剤師のコメントできる範囲を認 知し，ある程度患者との接触を経験している薬郕 師がカウンセリングすることが必要であろうと思 われた. 今回のわれわれの試みにおいては薬学部 教官は以前病院薬剤部に籍を置いた経験のある教 官であったことと病院薬剛部薬片師と 2 人 1つのチームを形成しカウンセリングを行ったこ とで，お互いに補足的な対応が可能となり，ス ムーズな対応ができたものと考えられる。このよ うな試みの輪を拡げる場合は，まったく患者との 接点を経験したことのない薬学部教官において は，薬羭部薬剤師との組み合わせのチームでカウ ンセリングを実施することが重要ではないかと考 えられた。

糖尿病に限らず, 薬学部教官の服薬カウンセリ ング参画はいろいろな疾患, 薬物療法で可能とな ると考えられる，たとえば，喘息，高血圧，ワル ファリン服薬患者, 無機製㓮服薬患者等である. 喘息については喘息教室として実際に日頃病院薬 片部で指導を行っていることが多く，病院薬䩹師 
とチームを組んでの服薬カウンセリングを行いや すい疾患であろうと思われる。ワルファリンなど は日常の食生活面での注意点が多く，いろいろな 薬物との相互作用も多い薬剤であることから患者 の生活環境を十分聞きながら行うカウンセリング には適しているものと考えられる，また，薬剛に 適合する薬学部教官を指名して服薬カウンセリン グを担当してもらうことも考えてよいと思われ る、たとえば, 薬学部で有機・無機化学を専攻し ている教官に無機薬剈，たとえば炭酸リチウム， 鉄剤等を服薬されている患者への服薬カウンセリ ングを打願いすることも可能性として考えてよい のではなかろうか.

学生に対する臨床実践教育の一環として薬学部 教官の参画する服薬カウンセリングを実施した が，患者とのカウンセリングを経験することで病 院薬剤部業務に携わっているという認識のもとに 薬学部での教育が行えるのではないかと考えられ る、また，学生も教官が患者と接する姿を見るこ とで，薬学部における教育がいかに臨床の現場と
密接につながったものであるかが理解できるもの と思われる，さらに，薬学部の教育現場に病院薬 剤師も参画し，病院薬剤師が自分の体験をもとに どのような観点で学生時代に学ぶべきであるか， あるいは臨床現場での薬凨師としての体験を講義 のなかで話す機会を増やすことも重要と考えられ る.すなわち薬学部教官と病院薬剤師の教育現場 への相互乗り入れを実現し，薬剤師養成教育に役 立てていく必要があるものと考えられる.

\section{引用文献}

1）“病院薬局研修ハンドブック 第 2 版”, 大阪大 学病院薬学研究会編, 薬業時報社, 東京, 1994.

2) 近畿地区薬学部学生実務実習に関する協議会監 修“薬学生のための病院薬局実習の手引き 1998年版”，日本病院薬剤師会近畿ブロック， 日本薬剤師会大阪・近畿ブロック(編), 薬業時 報社, 1998 .

3) 大和田栄治, 月刊薬事, 40, 1505-1508 (1998).

4) 平井みどり, 松田芳久, 月刊楽事, 40, 15171520 (1998).

5) 松山賢治, 月刊薬事, 40, 1521-1527 (1998).

6) 半谷傎七子, 日病薬誌, 34, 163-170 (1998). 